\title{
PENGARUH MARKETING MIX TERHADAP KEPUTUSAN KONSUMEN UNTUK ME- NABUNG PADA BANK PERKREDITAN RAKYAT PRISMA DANA AIRMADIDI KABU- PATEN MINAHASA UTARA
}

\author{
Charles R. Ngangi \\ Celsius Talumingan \\ Olvie L. S. Benu \\ Belinda Tatuh
}

\begin{abstract}
This study aimed to analyze the effect of marketing mix variables (product, price, promotion, and place) to the consumer's decision to save the Rural Bank Prisma Airmadidi Fund. The research was conducted in November to December 2010. The primary data obtained through interviews with 50 respondents, customers using questionnaire. Analysis using multiple linear regression with SPSS version 17.0. Hypothesis testing using test-f, t-test, and the coefficient of determination (R2).

The results showed that all four marketing mix variables jointly influence consumer decisions. Variable products and variable space has a positive and significant influence on consumer decisions, promotion variables have positive but not significant, while the price variable and no significant negative effect on consumer decisions. RB Prism Fund is expected to remain maintain product quality while expanding the market to increase the number of consumers / customers. The interest rate should be above the savings rate savings banks. Promotion strategies are needed in the form of prizes to increase the number of BPR Prism Funds.
\end{abstract}

Keywords: marketing mix, decision to save

\section{PENDAHULUAN}

\section{Latar Belakang}

Pada tahun 1997 kondisi perekonomian Indonesia sangat memprihatinkan karena terjadinya krisis moneter. Optimalisasi pemanfaatan sumber daya yang belum maksimal mengakibatkan persaingan yang sangat ketat diantara sesama perusahaan domestik maupun perusahaan multinasional serta adanya perubah-an perilaku konsumen yang kini semakin banyak tuntutan baik mengenai kualitas produk, harga maupun pelayanan. Sebelum krisis moneter perbankan nasional sedang mengalami proses menuju terwujudnya Prudential Banking Practices, mengenai usaha dalam memperkuat struktur permodalan perbankan nasional. Pembagian peran didalam perbankan yang membedakan dua jenis bank yaitu: bank umum dan bank perkreditan rakyat, telah mengakibat-kan seluruh target market perbankan menjadi perebutan dari semua bank.

Terjadinya krisis moneter telah mengakibatkan perbankan nasional mengalami tingkat suku bunga yang semakin meningkat Tingkat suku bunga yang semakin meningkat sebagai dampak dari melemahnya nilai tukar rupiah dan kualitas aktiva produktif yang memburuk telah mewajibkan bank-bank mem-punyai cadangan dana yang cukup. Krisis nilai tukar rupiah yang melemah diikuti dengan beberapa bank yang dilikuidasi mengakibatkan kepercayaan masyarakat terhadap perbankan nasional menurun. Untuk mengatasi hal-hal tersebut di- 
perlukan adanya perbaikan kinerja perbankan nasional, sehingga kepercayaan dari masyarakat kembali meningkat sejalan dengan kebijakan dan program pemerintah.

Peningkatan pelayanan perbankan kepada masyarakat merupakan jawaban terhadap kebutuhan ekonomi yang berkembang pesat. Antisipasi krisis telah diupayakan antara lain dengan mengembalikan kepercayaan masyara-kat terhadap perbankan nasional diantaranya melalui pemberian jaminan pemerintah berupa blanket guarantee kepada para penyimpan dana. Bank Perkreditan Rakyat Prisma Dana salah satu bank swasta juga menghadapi tantangan yang sama dengan bank-bank konvensional lainnya. Persaingan antar bank berimbas pada sulitnya menarik nasabah sebagai pelanggan tetap di BPR Prisma Dana.

Dalam rangka mengantisipasi persaingan yang lebih kompetitif maka BPR Prisma Dana dituntut untuk mampu bersaing dengan perbankan lain dan dapat menyesuaikan dengan perubahan kondisi yang terjadi pada saat ini. Untuk melakukan persaingan per-bankan seharusnya tidak hanya menitikberat-kan pada kelancaran pemberian dana (kredit) tetapi juga harus memperhatikan pula strategi dalam memasarkan program perbankan.

Keberhasilan strategi pemasaran dipengaruhi oleh beberapa faktor antara lain: riset dan analisa pasar, keputusan nasabah terhadap produk, penetapan harga (suku bunga), distribusi (tempat) dan promosi. Dalam me-masarkan sebuah produk yang dihasilkan perbankan perlu mengenal marketing mix yang berisi empat kegiatan utama dalam pemasaran. Marketing Mix (Kotler, 1994) adalah seperang-kat alat pemasaran khusus yang digunakan perusahan, yang terdiri dari produk, harga, promosi, dan tempat atau distribusi. Didalam mengantisipasi keadaan pasar yang semakin kompetitif ini maka kebijaksanaan yang dibuat oleh suatu perusahaan harus terpadu dan menyangkut marketing mix secara keseluruhan dan manajemen pada dasarnya tidak hanya menekankan pada salah satu aspek pemasaran saja apabila menginginkan hasil yang yang memuaskan.

BPR Prisma Dana adalah sebuah perusahaan jasa perbankan diharapkan mampu menjalankan fungsi perbankan yaitu menarik dana dari masyarakat kemudian menyalurkan kepada pihak-pihak yang memerlukan modal melalui fasilitas kredit. Salah satu cara mengumpulkan dana tersebut adalah melalui tabungan. Sikap konsumen (nasabah) merupak-an salah satu faktor eksternal yang kuat pengaruhnya terhadap perilaku seseorang.

\section{Perumusan Masalah}

Berdasarkan latar belakang yang diuraikan maka yang menjadi masalah dalam, penelitian ini adalah apakah variabel-variabel marketing mix berpengaruh terhadap keputusan konsumen untuk menabung di Bank Perkreditan Rakyat Prisma Dana dan variabel-variabel manakah yang paling berpengaruh.

\section{Tujuan dan Manfaat Penelitian}

Untuk menganalisis pengaruh variabel marketing mix (product, price, promotion, place) terhadap keputusan konsumen untuk menabung di BPR Prisma Dana.

Penelitian bermanfaat untuk memberikan masukan kepada manajemen BPR Prisma Dana tentang pengaruh marketing mix dengan keempat variabelnya terhadap keputusan konsumen menabung di BPR Prisma Dana, sehingga dapat dijadikan sebagai bahan per-timbangan yang dapat diterapkan dalam strategi pemasaran yang benar sehingga dapat mening-katkan jumlah pelanggan.

\section{METODOLOGI PENELITIAN}

\section{Metode Pengumpulan Data}

Data yang dikumpulkan dalam bentuk data primer dan sekunder. Data primer di peroleh dari wawancara langsung dengan responden berdasarkan daftar pertanyaan yang telah dis- 
iapkan. Data sekunder diperoleh dari Bank Perkreditan Rakyat Prisma Dana yang terkait dalam penelitian ini.

\section{Metode Pengambilan Sampel}

Populasi dalam penelitian ini adalah pengguna jasa layanan BPR atau nasabah. Jumlah nasabah BPR Prisma Dana Airmadidi sebanyak 557 orang. Sampel dalam penelitian ini diambil sebanyak 50 orang nasabah dengan menggunakan metode purposive random sampling.

\section{Konsep Pengukuran Variabel}

Variabel dalam penelitian ini antara lain :

1. Variabel bebas (independent variable)

Variabel bebas merupakan variabel yang variasinya mempengaruhi variabel lain. Variabel bebas berikut ini diukur dengan menggunakan penilaian skor (1-5) dari pertanyaan-pertanyaan pada kuisioner yang diberikan kepada konsumen. Pengukuran ini diambil melalui pendekatan pada konsumen.

a) Produk (product): penilaian jenis produk, model/tampilan, kualitas, kelebihan/keunggulan produk tabungan untuk menabung pada BPR Prisma Dana.

b) Harga (price): suku bunga yang ditawarkan, syarat untuk menabung, suku bunga yang ditawarkan sudah sesuai dengan mutu produk, kemudahan bertransaksi untuk menabung pada BPR Prisma Dana.

c) Promosi (promotion): frekuensi promosi, hadiah secara langsung, efektifitas komunikasi saat promosi, bonusbonus yang diberikan, iklan tentang produk tabungan pada BPR Prisma Dana.

d) Tempat (place): jangkauan pemasaran produk, fleksibilitas jarak lokasi, efi- siensi waktu untuk menabung pada BPR Prisma Dana.

2. Variabel tidak bebas (dependen variabel): Variabel tidak bebas merupakan variabel yang terpengaruh oleh variasi variabelvariabel bebas. Variabel tidak bebas dalam penelitian adalah keputusan konsumen untuk menabung yang diukur dengan melakukan pendekatan kepada konsumen terhadap produk tabungan apa yang mereka inginkan.

\section{Definisi Pengukuran Variabel}

Variabel-variabel berikut ini diukur dengan menggunakan skor pada kuisioner, diuraikan pada Tabel 1.

\section{Waktu dan Tempat Penelitian}

Penelitian ini dilakukan dari bulan November sampai Desember 2010. Sedangkan tempat penelitian dilakukan pada Bank Perkreditan Rakyat Prisma Dana Airmadidi.

\section{Metode Analisis Data}

Data dalam penelitian ini dikumpulkan kemudian disajikan dalam bentuk tabel dan untuk menganalisis pengaruh variabel marketing mix (produk, harga, promosi, tempat) digunakan metode statistik dengan analisis regresi linier berganda. Analisis ini digunakan untuk mengetahui bagaimana pengaruh dari variabel produk, harga, promosi, dan tempat sebagai variabel bebas terhadap variabel keputusan konsumen untuk menabung sebagai variabel tidak bebas. Persamaan regresi linear berganda menurut $\mathrm{Gu}-$ jarati (1996) sebagai berikut:

$$
Y=\beta_{0}+\beta_{1} X_{1}+\beta_{2} X_{2}+\beta_{3} X_{3}+\beta_{4} X_{4}+e
$$

Dimana:

$\begin{array}{ll}\mathrm{Y} & =\text { Keputusan Konsumen } \\ \mathrm{X} 1 & =\text { Produk } \\ \mathrm{X} 2 & =\text { Harga } \\ \mathrm{X} 3 & =\text { Promosi }\end{array}$




$$
\begin{array}{ll}
\mathrm{X} 4 & =\text { Tempat } \\
\beta_{1,} \beta_{2,} \beta_{3,} \beta_{4} & =\text { Koefisien variabel } \mathrm{X}_{1}, \mathrm{X}_{2}, \mathrm{X}_{3}, \mathrm{X}_{4} \\
\beta_{0} & =\text { Konstanta } \\
\mathrm{e} & =\text { Kesalahan prediksi (error) }
\end{array}
$$

\section{Pengujian Hipotesis}

Untuk membuktikan ada tidaknya pengaruh yang signifikan maka dilakukan uji-f, ujit dan $R^{2}$.

a) Uji-f (overall test) untuk mengetahui apakah semua variabel independen yang digunakan dalam model regresi secara bersama-sama berpengaruh pada variabel bebas.

$\mathrm{H}_{0}=$ Keempat variabel bebas tidak berpengaruh terhadap variabel tidak bebas.

$\mathrm{H}_{1}=$ Keempat variabel bebas berpengaruh terhadap variabel tidak bebas.

Dasar pengambilan keputusan:

1) Jika probabilitas (signifikansi) $<(\alpha) 0,05$ maka $\mathrm{H}_{0}$ ditolak atau

2) Jika probabilitas (signifikansi) $<(\alpha) 0,05$ maka $\mathrm{H}_{1}$ diterima

b) Uji-t (partial test), untuk mengetahui pengaruh variabel bebas secara parsial terhadap variabel tidak bebas dengan asumsi variabel yang lain konstan.
$\mathrm{H}_{0}=$ Keempat variabel bebas tidak berpengaruh terhadap variabel tidak bebas.

$\mathrm{H}_{1}=$ Kedua variabel bebas (produk dan tempat) berpengaruh terhadap variabel tidak bebas.

Dasar pengambilan keputusan menurut Santoso (2004):

1) Jika probabilitas (signifikansi) $<(\alpha) 0,05$ maka $\mathrm{H}_{0}$ diterima

2) Jika probabilitas (signifikansi) $<(\alpha) 0,05$ maka $\mathrm{H}_{0}$ ditolak dan terima $\mathrm{H}_{1}$

c) Uji $\mathrm{R}^{2}$ (coeficient determinant) untuk melihat kekuatan variabel bebas menjelaskan variabel tidak bebas. Besarnya koefisien determinasi $\left(\mathrm{R}^{2}\right)$ adalah 0 sampai 1 . Semakin mendekati 1 besarnya koefisien determinasi suatu persamaan regresi semakin besar pula pengaruh semua variabel bebas terhadap variabel tidak bebas (semakin besar kemampuan model dalam menjelaskan perubahan nilai variabel tidak bebas). Sebaliknya semakin mendekati nol besarnya koefisien determinasi suatu persamaan regresi semakin kecil pula pengaruh semua variabel bebas terhadap nilai variabel tidak bebas (semakin kecil kemampuan model yang menjelaskan perubahan nilai variabel tidak bebas). Besarnya pengaruh variabel bebas secara parsial dilihat dari besarnya determinasi parsial $\left(\mathrm{R}^{2}\right)$. 
Tabel 1. Pengukuran Variabel Penelitian

\begin{tabular}{|c|c|c|c|}
\hline No. & Variabel yang diukur & Indikator & Pengukuran \\
\hline \multirow[t]{5}{*}{1} & \multirow{3}{*}{$\begin{array}{l}\text { Produk adalah jenis-jenis } \\
\text { tabungan yang kompleks } \\
\text { dapat diraba maupun tidak } \\
\text { dapat diraba yaitu termasuk } \\
\text { bentuk, kualitas serta kele- } \\
\text { bihan yang ditawarkan ke- } \\
\text { pada nasabah untuk memua- } \\
\text { skan keinginan atau kebutu- } \\
\text { hannya. }\end{array}$} & Jenis-jenis produk & $\begin{array}{l}5 \text { point skor mulai dari 1(tidak bagus), } 2 \text { (kurang ba- } \\
\text { gus), 3(cukup bagus), 4(bagus) dan } 5 \text { (sangat bagus } \\
\text { sekali) }\end{array}$ \\
\hline & & Model tampilan produk & $\begin{array}{l}5 \text { point skor mulai dari 1(tidak bagus), } 2 \text { (kurang ba- } \\
\text { gus), 3(cukup bagus), 4(bagus) dan } 5 \text { (sangat bagus } \\
\text { sekali) }\end{array}$ \\
\hline & & Kualitas produk & $\begin{array}{l}5 \text { point skor mulai dari 1(tidak bagus), 2(kurang ba- } \\
\text { gus), } 3 \text { (cukup bagus), 4(bagus) dan } 5 \text { (sangat bagus } \\
\text { sekali) }\end{array}$ \\
\hline & & Manfaat Produk & $\begin{array}{l}5 \text { point skor mulai dari 1(tidak bagus), } 2 \text { (kurang ba- } \\
\text { gus), 3(cukup bagus), 4(bagus) dan } 5 \text { (sangat bagus } \\
\text { sekali) }\end{array}$ \\
\hline & & $\begin{array}{l}\text { Kelebihan yang dimiliki } \\
\text { produk dibandingkan } \\
\text { produk lain }\end{array}$ & $\begin{array}{l}5 \text { point skor mulai dari 1(tidak bagus), 2(kurang ba- } \\
\text { gus), } 3 \text { (cukup bagus), 4(bagus) dan } 5 \text { (sangat bagus } \\
\text { sekali) }\end{array}$ \\
\hline \multirow[t]{4}{*}{2} & \multirow{4}{*}{$\begin{array}{l}\text { Harga adalah tingkat suku } \\
\text { bunga dari masing-masing } \\
\text { produk tabungan yang dibe- } \\
\text { rikan untuk pemilihan ta- } \\
\text { bungan berdasarkan keingi- } \\
\text { nan dan kebutuhannya. }\end{array}$} & $\begin{array}{l}\text { Nilai tingkat suku bunga } \\
\text { masing-masing produk }\end{array}$ & $\begin{array}{l}5 \text { point skor mulai dari 1(sangat rendah), 2(rendah), } \\
3 \text { (cukup), 4(tinggi) dan } 5 \text { (sangat tinggi) }\end{array}$ \\
\hline & & $\begin{array}{l}\text { Syarat memperoleh suku } \\
\text { bunga }\end{array}$ & $\begin{array}{l}5 \text { point skor mulai dari 1(sangat memberatkan) } \\
\text { 2(berat), 3(cukup berat), 4(ringan) dan 5(sangat rin- } \\
\text { gan) }\end{array}$ \\
\hline & & $\begin{array}{l}\text { Tingkat suku bunga se- } \\
\text { suai mutu produk }\end{array}$ & $\begin{array}{l}5 \text { point skor mulai dari 1(tidak sesuai), 2(kurang se- } \\
\text { suai), 3(cukup sesuai), 4(sesuai) dan } 5 \text { (sangat sesuai) }\end{array}$ \\
\hline & & Kemudahan bertransaksi & $\begin{array}{l}5 \text { point skor mulai dari 1(tidak mudah) s/d 5(sangat } \\
\text { mudah sekali) }\end{array}$ \\
\hline \multirow[t]{5}{*}{3} & \multirow[t]{5}{*}{$\begin{array}{l}\text { Promosi adalah sumber in- } \\
\text { formasi dan komunikasi } \\
\text { yang dibuat untuk menga- } \\
\text { rahkan nasabah kepada tin- } \\
\text { dakan untuk menciptakan } \\
\text { pertukaran. }\end{array}$} & Frekuensi Promosi & $\begin{array}{l}5 \text { point mulai dari 1(tidak pernah), 2(jarang), 3(cukup } \\
\text { sering), 4(sering) dan 5(sangat sering) }\end{array}$ \\
\hline & & Hadiah secara langsung & $\begin{array}{l}5 \text { point skor mulai dari 1(tidak pernah), 2(jarang), } \\
3 \text { (cukup sering), 4(sering) dan 5(sangat sering sekali) }\end{array}$ \\
\hline & & $\begin{array}{l}\text { Efekstifitas promosi } \\
\text { (semakin besar target } \\
\text { yang dicapai makin } \\
\text { tinggi efektifitasnya) }\end{array}$ & $\begin{array}{l}5 \text { point skor mulai dari 1(sangat tidak efektif), 2(tidak } \\
\text { efektif), 3(cukup efektif), 4(efektif) dan 5(sangat } \\
\text { efektif) }\end{array}$ \\
\hline & & $\begin{array}{l}\text { Bonus-bonus yang dibe- } \\
\text { rikan produk }\end{array}$ & $\begin{array}{l}5 \text { point skor mulai dari 1(tidak pernah), 2(jarang), } \\
3 \text { (cukup sering), 4(sering) dan 5(sangat sering sekali) }\end{array}$ \\
\hline & & Pengaruh iklan & $\begin{array}{l}5 \text { point skor mulai dari 1(tidak } \text { berpengaruh), } \\
\text { 2(kurang } \text { berpengaruh),3(cukup } \\
\text { 4(berpengaruh) dan 5(sangat berpengaruh) }\end{array}$ \\
\hline \multirow[t]{2}{*}{4} & \multirow{2}{*}{$\begin{array}{l}\text { Tempat adalah pemilihan } \\
\text { lokasi yang mempertim- } \\
\text { bangkan kemudahan dan } \\
\text { meningkatkan kegunaannya } \\
\text { baik dalam mempertahan- } \\
\text { kan nasabah yang ada mau- } \\
\text { pun menarik nasabah yang } \\
\text { baru. }\end{array}$} & $\begin{array}{l}\text { Jangkauan pemasaran } \\
\text { produk }\end{array}$ & $\begin{array}{l}5 \text { point skor mulai dari 1(sangat tidak mudah dijang- } \\
\text { kau), 2(tidak mudah dijangkau) 3(cukup mudah), } \\
\text { 4(mudah dijangkau) dan 5(sangat mudah dijangkau) }\end{array}$ \\
\hline & & $\begin{array}{l}\text { Pemilihan lokasi } \text { BPR } \\
\text { dengan nasabah }\end{array}$ & $\begin{array}{l}5 \text { point skor mulai dari 1(sangat tidak mudah dijang- } \\
\text { kau), 2(tidak mudah dijangkau) 3(cukup mudah), } \\
\text { 4(mudah dijangkau) dan 5(sangat mudah dijangkau) }\end{array}$ \\
\hline
\end{tabular}

Tabel 1. Pengukuran Variabel Penelitian (sambungan) 


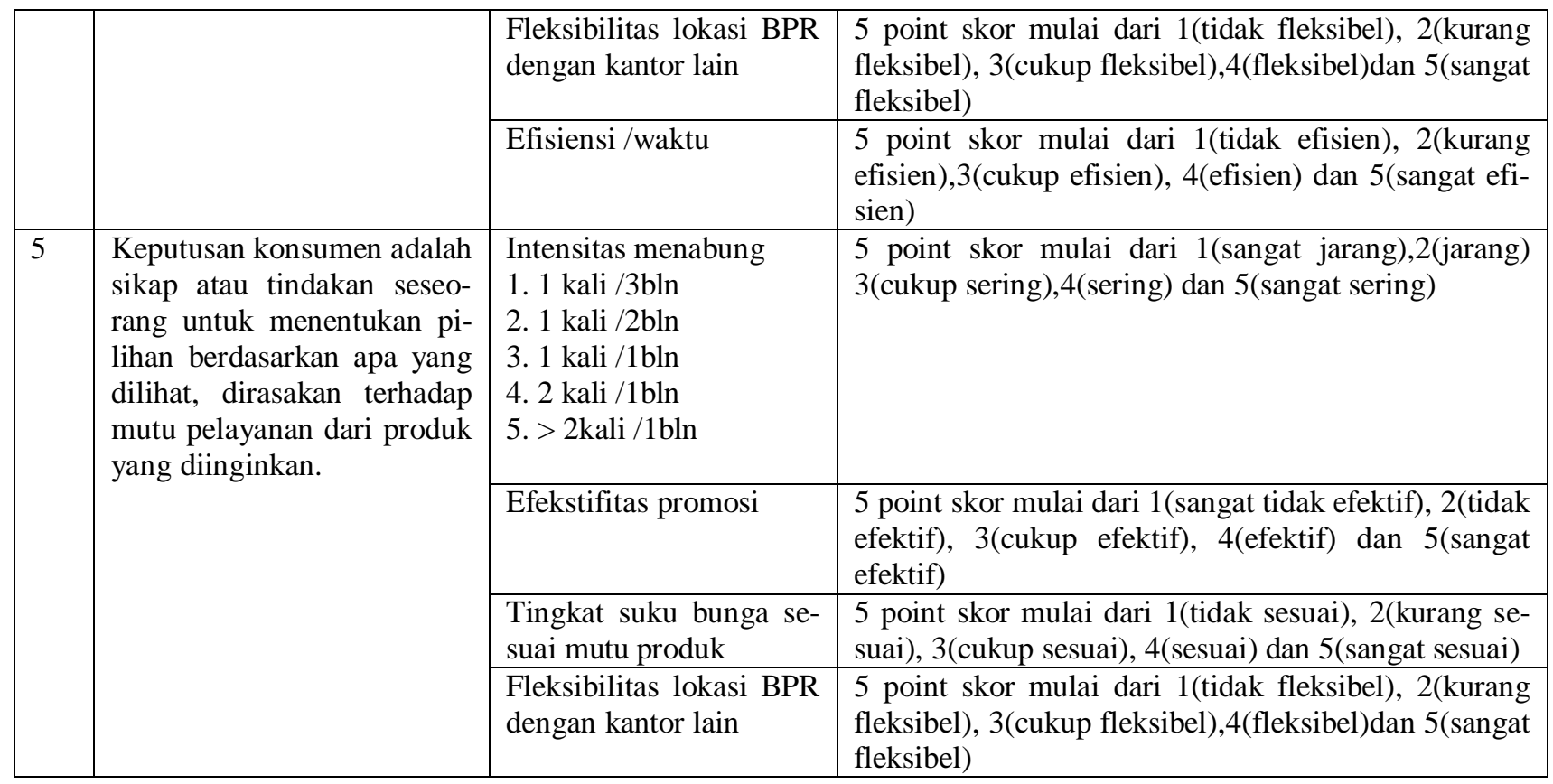

\section{HASIL DAN PEMBAHASAN}

\section{Karakteristik Marketing Mix}

\section{a. Produk $\left(\mathrm{X}_{1}\right)$}

Produk tabungan yang ada pada BPR Prisma Dana terdiri dari:

\section{1) Simapan (Simpanan Masa Depan)}

Merupakan jenis tabungan perorangan atau perusahaan yang penarikan dan penyetorannya dapat dilaksanakan setiap waktu sesuai ketentuan yang berlaku. Peserta simapan diikutsertakan dalam penarikan undian berhadiah setiap tahun berdasarkan pengendapan dana tabungan.

\section{2) Tabungan Prisma}

Merupakan tabungan yang diperuntukan menampung angsuran kredit dan dapat ditarik seluruhnya pada saat kredit yang di berikan lunas.

3) Karisma (Kelompok Arisan Prisma Dana) Merupakan jenis tabungan berkelompok yang mengadopsi budaya menabung dikalangan masyarakat Sulawesi Utara. Peserta karisma dii kutsertakan dalam undian berhadiah setiap bulan. Bentuk hadiah berupa uang tunai yang jumlah bertambah besar tiap periode penarikan undian.

\section{4) TabunganKu}

Merupakan jenis tabungan tanpa biaya administrasi. Syarat tabunganku setoran awal 10 ribu rupiah.

\section{b. Harga $\left(\mathrm{X}_{2}\right)$}

Harga dalam hal ini merupakan tingkat suku bunga pada setiap jenis produk tabungan. Besaran suku bunga pada tiap-tiap tabungan itu berbeda. Berikut ini merupakan tingkat suku bunga tabungan di BPR Prisma Dana :

Tabel 2. Suku Bunga Tabungan

\begin{tabular}{|l|c|}
\hline \multicolumn{1}{|c|}{ Jenis Tabungan } & $\begin{array}{c}\text { Suku Bunga } \\
(\%)\end{array}$ \\
\hline - Simapan & 7 \\
- Prisma & 3 \\
- TabunganKu & 4 \\
- Karisma & 0 \\
\hline
\end{tabular}

\section{c. Promosi $\left(\mathrm{X}_{3}\right)$}

Seluruh kegiatan untuk mengkomunikasikan jenis-jenis produk BPR Prisma Dana kepada konsumen untuk menabung. Unsur promosi dalam pemasaran jasa membentuk pe- 
ranan penting dalam membantu mengkomunikasikan posisi bank kepada para pelanggan dan masyarakat umumnya. Kegiatan promosi ini meliputi pameran perbankan, brosur, ataupun iklan.

\section{d. Tempat $\left(\mathrm{X}_{4}\right)$}

Tempat atau distribusi merupakan sarana yang meningkatkan suatu jasa yang akan menambah penggunanya atau pelanggannya. Baik dalam mempertahankan pelanggannya, meningkatkan kegunaannya diantara pelanggan yang ada ataupun untuk menarik pelanggan yang baru. Pemilihan lokasi sebuah kantor bank harus mempertimbangkan beberapa hal seperti: lokasi kantor pesaing, lokasi nasabah, tersedianya beberapa fasilitas yang akan digunakan bank seperti saluran telepon, listrik, tempat parkir yang luas serta sistem keamanan yang memadai.

Tabel 3. Rata-rata jumlah skor

\begin{tabular}{|lcccc|}
\hline & N & Minimum & Maximum & Mean \\
\hline - Keputusan & & & & \\
konsumen & 50 & 12,00 & 20,00 & 16,1600 \\
- Produk & 50 & 16,00 & 25,00 & 20,3200 \\
- Harga & 50 & 15,00 & 18,00 & 16,4800 \\
- Promosi & 50 & 15,00 & 20,00 & 16,8200 \\
- Tempat & 50 & 11,00 & 19,00 & 15,2000 \\
- Valid N (list- & 50 & & & \\
$\quad$ wise) & & & & \\
\hline Descriptive Statistics & & & & \\
\hline
\end{tabular}

Berdasarkan rata-rata jumlah skor diatas dapat dijelaskan bahwa sebagian besar nasabah lebih dulu memilih produk tabungan untuk menentukan keputusan menabung dibandingkan dengan faktor lainnya. Hal ini disebabkan karena berbagai variasi dari produk yang diunggulkan oleh BPR Prisma Dana sebagai alat untuk menarik pelanggan. Selain itu tempat atau lokasi menjadi bahan pertimbangan bagi nasabah untuk bisa menabung. Sedangkan promosi dan harga tidak terlalu diperhatikan oleh nasabah dikarenakan kurangnya promosi dan nasabah tidak terlalu memperhatikan tingkat suku bunga yang diberikan oleh BPR Prisma Dana.

\section{Analisis Regresi}

Berdasarkan data penelitian yang ada pada Lampiran 2 dilakukan analisis regresi dengan menggunakan alat bantu SPSS versi 17.0 maka diperoleh:

Tanel 4. Hasil Analisis Regresi

\begin{tabular}{|l|c|c|c|c|c|}
\hline \multirow{2}{*}{ Model } & \multicolumn{2}{|l|}{$\begin{array}{l}\text { Unstandardized } \\
\text { Coefficients }\end{array}$} & $\begin{array}{c}\text { Standar- } \\
\text { dized } \\
\text { Coeffi- } \\
\text { cients }\end{array}$ & $\mathrm{t}$ & Sig \\
\cline { 2 - 4 } & $\mathrm{B}$ & $\begin{array}{c}\text { Std. } \\
\text { Error }\end{array}$ & Beta & & \\
\hline Constant & $-1,739$ & 1,970 & & & \\
Produk & 0,588 & 0,086 & 0,637 & 6,803 & 0,382 \\
Harga & $-0,031$ & 0,072 & $-0,019$ & $-0,423$ & 0,000 \\
Promosi & 0,068 & 0,056 & 0,055 & 1,203 & 0,235 \\
Tempat & 0,350 & 0,096 & 0,332 & 3,634 & 0,001 \\
\hline
\end{tabular}

a. Dependent Variable: Keputusan Konsumen

Tabel 5. Analysis of Variance

\begin{tabular}{|llllll|}
\hline \multicolumn{1}{|c}{ Model } & $\begin{array}{l}\text { Sum of } \\
\text { Squares }\end{array}$ & df & $\begin{array}{c}\text { Mean } \\
\text { Square }\end{array}$ & F & Sig \\
\hline Regression & 166,465 & 4 & 41,616 & 131,375 & $0,000^{\mathrm{a}}$ \\
Residual & 14,255 & 45 & 0,317 & & \\
Total & 180,720 & 49 & & & \\
\hline
\end{tabular}

a. Predictors: (Constant), Tempat, Promosi, Harga, Produk

b. Dependent Variable: Keputusan_Konsumen

Persamaan regresinya, yaitu :

\section{Kep.Kons $=-\mathbf{1 , 7 3 9}+\mathbf{0 , 5 8 8}$ produk $-0,031$ harga + 0,068 promosi $+0,350$ tempat}

Nilai koefisien regresi masing-masing variabel adalah:

1) Koefisien regresi $\beta_{1}=0,588$ artinya, variabel produk berpengaruh positif terhadap keputusan konsumen.

2) Koefisien regresi $\beta_{2}=-0,031$ artinya, variabel harga berpengaruh negatif terhadap keputusan konsumen.

3) Koefisien regresi $\beta_{3}=0,068$ artinya, variabel promosi berpengaruh positif terhadap keputusan konsumen.

4) Koefisien regresi $\beta_{4}=0,350$ artinya, variabel tempat berpengaruh positif terhadap keputusan konsumen. 
a. Uji-f

\section{Pengujian Hipotesis}

Untuk menguji signifikansi dari persamaan regresi linier berganda secara keseluruhan digunakan uji-f. Cara yang digunakan dengan melihat probabilitas dari f pada $\alpha=5 \%$. Dari persamaan regresi tersebut diketahui bahwa nilai $\mathrm{p}=0,000<\alpha 5 \%$. Maka dapat disimpulkan $\mathrm{H}_{1}$ diterima, dimana variabel marketing mix (produk, harga, promosi dan tempat) untuk menabung pada BPR Prisma Dana secara bersama-sama berpengaruh nyata terhadap keputusan konsumen.

\section{b. Uji-t}

Untuk menguji signifikansi koefisien regresi untuk variabel produk, harga, promosi dan tempat maka digunakan uji-t, seperti diuraikan pada Tabel 6.

Tabel 6. Hasil Uji Parsial (uji-t)

\begin{tabular}{|l|c|l|l|}
\hline Variabel & \multicolumn{1}{|c|}{$\mathrm{P}$} & \multicolumn{1}{|c|}{ Signifikansi } & \multicolumn{1}{|c|}{ Kesimpulan } \\
\hline Produk & 0,000 & $\begin{array}{l}\text { Sangat Sig- } \\
\text { nifikan }\end{array}$ & $\begin{array}{l}\text { Secara parsial sangat } \\
\text { berpengaruh nyata } \\
\text { terhadap keputusan } \\
\text { konsumen untuk me- } \\
\text { nabung }\end{array}$ \\
\hline Harga & 0,674 & $\begin{array}{l}\text { Tidak signi- } \\
\text { fikan }\end{array}$ & $\begin{array}{l}\text { Secara parsial tidak } \\
\text { berpengaruh nyata } \\
\text { terhadap keputusan } \\
\text { konsumen untuk me- } \\
\text { nabung }\end{array}$ \\
\hline Promosi & 0,235 & $\begin{array}{l}\text { Tidak signi- } \\
\text { fikan }\end{array}$ & $\begin{array}{l}\text { Secara parsial tidak } \\
\text { berpengaruh nyata } \\
\text { terhadap keputusan } \\
\text { konsumen untuk me- } \\
\text { nabung }\end{array}$ \\
\hline Tempat & 0,001 & $\begin{array}{l}\text { Sangat sig- } \\
\text { nifikan }\end{array}$ & $\begin{array}{l}\text { Secara parsial sangat } \\
\text { berpengaruh nyata } \\
\text { terhadap keputusan } \\
\text { konsumen untuk me- } \\
\text { nabung }\end{array}$ \\
\hline
\end{tabular}

\section{c. Koefisien Determinasi}

Koefisien Adjusted $R$ Square digunakan untuk mengukur kontribusi dari variabel bebas terhadap variabel terikat. Adjusted $R$ Square sebesar $91 \%$ menunjukkan bahwa $91 \%$ keputusan konsumen untuk menabung pada Bank Perkreditan Rakyat Prisma Dana dapat dijelaskan variabel produk, harga, promosi dan tempat, sedangkan sisanya $9 \%$ dipengaruhi oleh variabel lain yang tidak diteliti dalam penelitian ini.

\section{KESIMPULAN DAN SARAN}

\section{Kesimpulan}

Berdasarkan hasil penelitian disimpulkan bahwa keempat variabel marketing mix secara bersama-sama berpengaruh nyata terhadap keputusan konsumen untuk menabung. Namun secara parsial, variabel produk dan variabel tempat berpengaruh positif dan signifikan terhadap keputusan konsumen untuk menabung. Variabel promosi berpengaruh positif tetapi tidak signifikan, sedangkan variabel harga berpengaruh negatif dan tidak signifikan terhadap keputusan konsumen untuk menabung.

\section{Saran}

BPR Prisma Dana diharapkan tetap mempertahankan kualitas produk sambil melakukan ekspansi pasar untuk meningkatkan jumlah konsumen/nasabah. Tingkat suku bunga tabungan harus berada di atas tingkat suku bunga tabungan bank-bank umum. Diperlukan strategi promosi dalam bentuk hadiah-hadiah menarik untuk meningkatkan jumlah nasabah BPR Prisma Dana.

\section{DAFTAR PUSTAKA}

Aaltonen, P. G., 2004. “Customer Relationship Marketing and Effect of Demographics and Technology on Customer Satisfaction nd Loyality in Financial Services" Old Dominion University.

Anonimous, 2007. Manajemen Mix Terhadap Keputusan Konsumen. Manado.

Abas K. 1996. Riset Konsumen Dalam Pengembangan Teori Perilaku Konsumen dan Masa Depannya. Jurnal Bisnis Ekonomi Dan Bisnis Indonesia. Vol. 14 No.1.

Basu S. 2000. Azas-Azas Marketing, Edisi III. Liberty. Yogyakarta. 
Cannon and Riordan. 1994. Pemasaran Strategis. Jilid 1-2 (Edisi Terjemahan). Erlangga.

Ghozali, I. 2001. Aplikasi Analisis Multivariate Dengan Program SPSS Versi 17.0. badan Penerbit Universitas Dipenogoro.

Gie, K.K., 1997, dalam "Ensiklopedi Ekonomi, Bisnis, Manajemen". Penerbit Delta Panangkal, Jakarta.

Gujarati, D. 1996. Ekonometrika Dasar. Edisi VI. Jakarta: Erlangga.

http://www.selfempoweringtips.com/decisionmaking/Consumer-Decision-MakingProcess.html diakses pada tanggal $28 \mathrm{Ma}-$ ret 2011, jam 16.30 Wita http://www.consumerpsychologist.com/ diakses pada tanggal 28 Maret 2011, jam 17.10 Wita

Kotler dan Amstrong. 1991. Dasar-Dasar Pemasaran. CV Intermedia, Jakarta.

Kotler, P., 1994. Manajemen Pemasaran - Analisis Perencanaan dan Implementasi dan Pengendalian. CV Intermedia. Jakarta.

Soekarno K, 1986. Dasar-Dasar Manajemen. Mizwar. Jakarta.

Soekartawi, 1988. Prinsip Dasar Manajemen Pemasaran Hasil-Hasil Pertanian. PT. Raja Grafindo Persada, Jakarta 